\title{
ФІЛОСОФІЯ
}

УДК 316.324.7:37]:316.276

DOI https://doi.org/10.32837/apfs.v0i28.939

\section{ДУХ ЕПОХИ ЯК ПЕРЕДВІСНИК ЦИВІЛІЗАЦІЙНОГО РУХУ СОЦІАЛЬНОЇ СИСТЕМИ ІНДУСТРІАЛЬНОЇ ОСВІТИ}

Постановка проблеми. Сьогодні головна увага освітян всього світу прикута до трансформації наявних національних систем освіти, що явно тяжіють до глобалізації і уніфікації у планетарному просторі. Тому усе частіше у публікаціях вітчизняних i зарубіжних авторів починають використовуватися такі терміни, як «глобальна освіта», «глобалізація освіти», «планетарна освіта» тощо. При цьому існує явна недооцінка явища інформатизації освіти, що веде до якісної зміни навчально-виховної діяльності у сфері освіти, що дійсно глобалізується.

Аналіз останніх досліджень і публікацій. Передвісником якісної зміни у життєвому устрої планетарної спільноти є так званий дух епохи. Його дія розповсюджується й на освітянську сферу. Термін педагогічній сфері явно не притаманний, але саме від нього багато що залежить у змісті й формах освіти дітей і дорослих, у загальній і професійній школі. Тут термін «школа» ми вживаємо у широкому сенсі слова. При цьому це явище завжди передує наступним змінам у освітянському просторі. Зазначимо, що у всеохоплюючому виданні АПН України «Енциклопедія освіти" за редакцією В. Кременя такого терміну немає [1, с. 1040].

Формулювання мети статті. Якщо нас цікавить майбутне освіти інформаційної доби, то спрогнозувати їі зміст і зміни ми можемо за допомогою відтвореного алгоритму зміни духу індустріальної доби. 3 тією поправкою, що «еволюція теж перебуває в процесі радикальної реконцептуалізації» [2, с. 480]. Це означає, що прямої аналогії організаційних форм перехідних етапів між різними цивілізаціями годі чекати, але загальний алгоритм має зберегтися, оскільки соціальні системи живуть за спільними законами. За таких умов метою статті є аналіз змін духу епохи в підсвідомості планетарної спільноти у часи виходу на поверхню планетарного життя інформаційної доби з тим, щоб можна було передбачити, як цей феномен буде запроваджуватись у наш життеустрій протягом XXI ст.

Силу впливу явища духу епохи на життя планетарної спільноти можна уявити, виходячи з відомих слів Г. Гегеля про те, що «якщо тільки дух народу піднімається на більш високий рівень, всі моменти державного устрою, пов'язані з попередніми рівнями його розвитку, втрачають свою усталеність, вони повинні занепасти, і не існуе сили, здатної їх утримати» [3, с. 438].

Тож для подальшого розгортання науково-пошукової роботи нам необхідно визначитись 3 двома вихідними моментами: по-перше, з яких етапів складається життєвий цикл системи індустріальної освіти, а по-друге, що таке «дух епохи» $\mathrm{i}$ як його трактують дослідники у дискурсі філософії освіти.

Виклад основного матеріалу. Щодо першого методологічного зауваження зазначимо таке: у низці публікацій, що викладені у різних фахових виданнях для обговорення широкою освітянською і педагогічною громадами, ми ретельно дослідили життєвий цикл соціальної системи індустріальної доби. Він складається, на нашу думку, з чотирьох етапів, а саме: зародження - XVI (1543) - кінець XVII ст.; зростання - кінець XVII ст. - кінець XIX ст.; зрілість - кінець XIX (1895) - 70-ті роки $\mathrm{XX}$ ст.; занепад - 70-і роки XX ст. - початок XXI ст. При цьому став очевидним той факт, що система освіти як соціальне явище підкоряється різним механізмам, що забезпечують її буття у часі й просторі: на етапі зародження діють закономірності самоорганізації і саморегуляції соціальних структур; зростання - гомеорезу; зрілості гомеостазу; занепаду - гомеоклазу.

Щодо другого методологічного зауваження, то вважаємо за доцільне звернутися до характеристики смислу і змісту явища духу епохи, що подано у праці В. Андрущенка «Філософія як теорія 
і методологія розвитку освіти». В ній дослідник зазначає таке: «Основний зміст «духу епохи» формується насамперед як філософське узагальнення, пояснення й оцінка сенсу, причинних зв' язків і тенденцій розвитку буття людини в світі, яке розгортається в наявних формах культури. Другим складником є порівняння означеного сенсу з досвідом історії, тобто із сенсом буття людини в світі загалом. Третій складник становить прогноз перспективи людського розвитку, його джерел і спонукальних чинників. "Дух епохи», таким чином, є нічим іншим, як філософським узагальненням найвеличніших наукових і культурних надбань, виходячи з яких, людство вибудовує свою соціальність, проектує майбутнє, готує до життя в ньому підростаюче покоління» [4, с. 17-23].

Топологічно це явище знаходиться у царині колективної підсвідомості планетарної спільноти, тобто належить і підтримується психосферою людини (терлін - О. Донченко). Це явище (мається на увазі дух епохи) скоріше інтуїтивно відчувається людиною, ніж свідомо відтворюється її теоретичною думкою, але від цього не стає більш поблажливим до долі як пересічної людини, так і ще донедавна могутніх національних держав. Сучасна криза соціального розвитку про це свідчить більш ніж переконливо. Саме дух нової епохи розбурхав наприкінці XX ст. планетарний світ і він прийшов у стан самоорганізації шляхом переструктурування самої матриці планетарного життя.

Далі є сенс повернутись до аналізу життєвого циклу соціальної системи індустріальної освіти і поетапно проаналізувати, як змінювався дух епохи і які новації він викликав до життя.

Ha emani зародження системи індустріальної освіти «дух епохи» був насичений гострими протистоянням ідей Середньовіччя і Нового часу. Це були повністю несприятливі для неї умови. Агресивність релігійної спільноти, що войовничо відстоювала свої позиції у суспільстві, набуті протягом довгого Середньовіччя, зводила нанівець саму можливість породження нових ідей, не кажучи вже про породження нової системи освіти і виховання. Про це свідчить майже двохсотрічна боротьба руху Реформації з гегемонією релігійної віри над науковим знанням у духовній сфері аграрного суспільства, що була у XVI-XVII ст. подолана за допомогою підключення до неї Просвітницького руху і руху Реформації. Початок перших революційних змін у середньовічному суспільстві та його духовних підсистемах ми пов'язуємо з виходом у 1543 році фундаментальної праці М. Коперника «О вращении небесных сфер», в якій обгрунтовано геліоцентричну систему світу, що перевернула уяву вчених про нерухомість Землі у Всесвіті. [5, с. 653]. Наукова революція, що викликана його відкриттям, відкинула теорії античних астрономів про положення небесних світил і дала поштовх для наукової рефлексії щодо природи та її процесів. В кінці кінців «дух епохи» було пом' якшено завдяки введенню до його складу ідей гуманізму і виведення на перші ролі значення людини.

На етапі зростання силами науки, що почала бурхливо розвиватися, зокрема завдяки класичній філософіï у ранзі модерну, модерновому мистецтву і літературі, архітектурі і театру та їх продуктам, наукова картина світу, світогляд, ідеологія, педагогічні концепції навчання і виховання отримали новий зміст і визнання своєї корисності у новому суспільстві.

Починаючи з Нового часу в усіх названих сферах спільними є віра в силу людського розуму, його невичерпні можливості пізнання світу. I в науці, і в філософії, і в мистецтві цього історичного відрізку становлення людського суспільства здійснюються спроби побудувати всеосяжні замкнені філософські, наукові системи Всесвіту, які б претендували на повне знання про світ, про людину, їі природні і розумові здібності.

$\mathrm{У}$ його просторі одночасно непомітно сформувалась загроза для життєвого устрою планетарної спільноти, оскільки дух епохи потроївся: по-перше, дух релігійності продовжував мати свій вплив на свідомість пересічної людини; по-друге, виокремився i почав стало функціонувати «дух капіталізму»; по-третє, марксистами започатковано формування "духу комунізму», що як привид почав бродити у цей час серед атеїстично налаштованого населення Європи і світу. Протистояння мало непримиренний характер і тому стало реальною загрозою для подальшого соціального розвитку двох ідеологічно непримиренних систем - капіталізму і соціалізму.

На emani зрілості функціонування системи індустріальної освіти, що відбувалось, за нашою класифікацією, у період з кінця XIX, а саме 3 1895 р. по 70-ті роки XX століття, ознаменувалось відкриттям радіоактивності. Це час так званої Новітньої історії - термін історіографії, період всесвітньої історії, що починається з 1914 року й, на думку одних істориків, завершився наприкінці 80-х - на початку 90-х pp. ХХ ст., на думку інших, триває досі, [9, с. 141-153]. При цьому протистояння носіїв різних сегментів «духу епохи» вилилось у непримиренну ворожнечу. Поки дух релігіозності тихенько відійшов у тінь, зачаївшись там, «дух капіталізму» та «дух комунізму» у цей час утворили «дух мілітаризму» і обидва розчинилися в ньому, результатом чого стали дві гарячі світові війни, що перейшли у затяжну «холодну війну» 3 низкою драматичних криз на Кубі (1962 р.), у Польщі (1956 р.), Чехословаччині (1968 р.) та деяких інших країнах так званого соціалістичного табору. 
Ha emani занепадy "дух епохи» дещо вирівнявся, оскільки "дух комунізму» на планетарній арені отримав історичну поразку, що завершилась у 1991 році саморозпадом СРСР, і на неї повернувся з активною соціальною позицією «дух релігії» навіть у просторі колишніх соціалістичних країн.

Характерно, що з 70-х років XX ст. і до поточного часу (перша чверть XXI ст.) «дух епохи», попри самоліквідацію СРСР, не змінив свій мілітаристський характер, а навпаки, став більш агресивним: по-перше, за рахунок імперських замашок Росії, що утворила навколо себе кільце нестабільності, а за його межами стала учасником багаточисельних військових конфліктів у низці країн Африки, Середнього Сходу, України; по-друге, завдяки намаганням США зайняти лідерську позицію на світовій арені, попри нарощення напруги у соціальному організмі своєї країни; по-трете, завдяки бурхливому сплеску міжнародного тероризму, руху антиглобалістів, усталених сепаратиських рухів за відділення територій у низці країн світу.

На основі вищевикладеного можна зробити висновок, що простір індустріальної цивілізації увесь час був просякнутий суперечливими тенденціями у сфері духовного життя планетарної спільноти. На етапі зародження це було протистояння релігійного і світського (гуманістичного), на етапі становлення - релігійного, капіталістичного і комуністичного, на етапі зрілості - капіталістичного і комуністичного, а на етапі занепаду - капіталістичного, залишків комуністичного і відродження релігійного духу. Загалом картина виглядає наступним чином (див. таблицю 1).

Не дивно, що інтегратором тут увесь час виступав дух непримиренності і мілітаризму. Як формувалась така атмосфера на планеті добре видно з тогочасної філософії, мистецтва, літератури, театру і кіно. Урівноважувалась надлишково мілітаризована атмосфера двома світовими «гарячими» і «холодними» війнами, локальними війнами, регіональними військовими конфліктами, безкінечними санкціями проти окремих держав, терористичними акціями і протестними рухами економічного, гендерного, кліматичного і антиглобалістського спрямування.

Звісно, що за таких зовнішніх умов система індустріальної освіти не могла довго протриматись у режимі сталого функціонування і вона швидко увійшла у режим саморозпаду, оскільки цьому негативному процесу, щоправда з іншим знаком впливу, сприяв розвиток науки і свідомості населення планети.

Вплив духу епохи на культуру і її невіддільний складник - освіту планетарної спільноти, відповідно до саморозгортання життєвого циклу індустріальної цивілізації - можна прослідкувати, на нашу думку, на праці М. Фуко «Слова и вещи», що присвячена нарису історії європейської культури від Відродження до середини XX ст. [6]. Як бачимо, хронологічні рамки цих двох досліджень повністю співпадають. «Еволюція культури» постає як послідовна зміна парадигми знання. Їх Фуко називає епістеми. Епістема по-грецьки - знання, пізнання. У Фуко це система уявлень про те, що і як потрібно і можна пізнавати. Це рушійна сила культури, якщо не саме її сутність. Починає він 3 Відродження. Хоча мається на увазі і фундамент цієї епохи - Середньовіччя. Фуко вважає, що цей час визначає епістема подібності або подоби. Вся система середньовічного і ренесансного знання була заснована на принципі подібності. Це означає, що людина шукає в світі подібності між речами. Світ влаштований не абияк. Якщо віддалені один від одного речі в чомусь виявляють подібності, то значить, що вони тісно або таємним чином пов'язані, і це мета пізнання і одночасно істина. Це добре проявляється на прикладі медичного знання Середньовіччя. Якщо травичка жовтого кольору, нею можна лікувати жовтяницю. Якщо квітка орхідеї за формою нагадує яйце, то її квітками можна лікувати венеричні хвороби. Богословські теми також пронизані ідеєю подібності. Коли Леонардо да Вінчі винаходить літальні апарати, він виходить з принципу подібності, тобто зі структурної подібності між істотами, які літають, і тими апаратами, які він винаходить. А вивчення законів, які дозволяють літаючим істотам долати силу тяжіння, використовуючи повітря, саме по собі ніби другорядне. У всьому людина прагне побачити принцип загального взаємозв'язку, великого ланцюга буття, в якому все зчеплене. Цьому принципу і прагненню підпорядкована думка Середньовіччя і Відродження.

В епоху Просвітництва приходить епістема відмінності. Тепер ця епоха «культу розуму» проповідує розум як можливість відрізняти одне від іншого, розкладати на елементи, аналізувати -

Динаміка трансформації «духу епохи» у горизонті індустріальної доби

\begin{tabular}{|l|l|l|l|l|}
\hline ЕТАП/ ЧИННИК & \multicolumn{1}{|c|}{ ЗАРОДЖЕННЯ } & \multicolumn{1}{|c|}{ ЗРОСТАННЯ } & \multicolumn{1}{|c|}{ ЗРІЛІСТЬ } & \multicolumn{1}{c|}{ ЗАНЕПАД } \\
\hline $\begin{array}{l}\text { Часовий вимір } \\
\text { (роки) }\end{array}$ & XVI-XVII ст. & $\begin{array}{l}\text { кінець XVII - } \\
\text { кінець XIX ст. }\end{array}$ & $\begin{array}{l}\text { кінець XIX ст. }- \\
70 \text { роки XX ст. }\end{array}$ & $\begin{array}{l}70 \text { роки XX - } \\
\text { початок XXI ст. }\end{array}$ \\
\hline Дух епохи & $\begin{array}{l}\text { Дух середньовіччя 3 } \\
\text { флуктуаціями Ренесансу, } \\
\text { Реформації і релігійності }\end{array}$ & $\begin{array}{l}\text { Дух класової боротьби } \\
\text { (К. Маркс, Е. Тоффлер) }\end{array}$ & $\begin{array}{l}\text { Гарячі локальні } \\
\text { i холодна війна }\end{array}$ & $\begin{array}{l}\text { Дух планетарної катастрофи } \\
\text { глобалізації, екологічної, } \\
\text { військової загрози }\end{array}$ \\
\hline
\end{tabular}


виділяти якісь компоненти і намагатися встановити відносини між ними, класифікувати. Сам принцип Енциклопедії свідчить про це. Знання про все, представлене у вигляді каталогу. Цей принцип зберігся донині. Енциклопедія як каталог всіх речей - образ епістеми відмінностей.

У XIX столітті, ближче до кінця його, стверджується епоха третьої епістеми - вона існує до нашого часу: епістема систем і організацій. Значить, були розрізнення, реєстри - після них тепер потрібно повернутися до ідеї цілого і навчитися всім цим різноманіттям знання якось керувати. Виникає епістема систем і організацій. Епоха філософії систем у німецькому ідеалізмі, еволюційна теорія Дарвіна - системні зв'язки між видами, типи взаємодії. Людина починає бачити світ як систему взаємодій. Донині це багато що визначає в науці. До сих пір ми ще до кінця не вийшли з цієї конфігурації думки. Фуко вже застав століття наростання інформаційних технологій, передбачає, що людство перебуває на порозі нової, четвертої епістеми. Свідками їі формування, можливо, є ми. Що може прийти на зміну епістеми систем і організацій, прикладом якої є будь-яке наукове знання зараз. Окремо взята наука існує, щоб зі спостережень будувати системи. Чи то систему Менделєєва або системи в економіці чи політології. У століття інформації може встановитися щось на зразок епістеми контролю. Людина спочатку все уподібнювала, потім поділяла, потім зібрала в систему. Що тепер з цим робити? Людина тепер хоче контролювати світ, себе та інших. Епістема контролю проявляється в тому, що над усіма уявленнями про системи та організації панує можливість доступу до інформації. Влада дає доступ до інформації та можливість маніпулювати нею, а через неї маніпулювати людьми» [7]. Залежно від саморозгортання духу епохи зміни відбувались у всій системі духовного супроводу цивілізаційного руху планетарної спільноти від філософії, наукової картини світу, світогляду, ідеології до виду знань і педагогіки.

Педагогіка, як специфічна технологія навчання і виховання людини, також пройшла низку специфічних змін, що були зумовлені станом духу епохи відповідно до етапів життєвого циклу соціальної системи індустріальної освіти. Не вдаючись до довгих пояснень, вкажемо лише на те, що вона пройшла шлях від стихійної форми до класичної, потім - концептуальної i, нарешті, на етапі занепаду отримала форму гібридної або маніпулятивної педагогіки.

Щодо цього здаються пророчими такі слова Альберта Ейнштейна: «Я боюсь, що настане той день, коли технології перевершать просте людське спілкування і ми отримаємо покоління ідіотів». А французький доктор нейропсихології Мішель Демюрже у книзі «Фабрика екранних ідіотів», що вийшла у 2019 році і стала бестселером у Франції, свідчить про те, що цей прикрий прогноз Альберта Ейнштейна цілком виправдався. Праця про вплив нових технологій на розвиток підростаючого покоління вийшла достатньо лякаючою. Починаючи з 2000-х років середній IQ молоді саме у розвинених країнах поступово знижується. Франція не виняток: з 1999 року по 2009 рік середній IQ французів знизився на 3,8 пункти.

Цілком логічно постає питання про те, якими параметрами можна охарактеризувати на початку XXI ст. притаманний йому дух інформаційної епохи. Явище ще повністю не визріло, але 3 впевненістю можна зазначити, що ще наприкінці XX століття «дух епохи» знову піднявся на якісно іншу ступінь розвитку, розбурхавши ментальні засади світового етносу і зруйнував ідеали людини, що були притаманні техногенній цивілізації.

Ми тут цілком згодні з характеристикою духу перехідного періоду від індустріальної до інформаційної цивілізації, що подана у колективній праці вчених Драгоманівського університету «Особистість у вирі планетарного світу» (2019), а саме $з$ тим, що «по-перше, цивілізаційний підхід системно висвітлює міжцивілізаційний зсув, у який потрапила планетарна спільнота, оскільки здійснюється спонтанний стрибок від техногенної до інформаційної цивілізації; по-друге, організаційна матриця планетарного життєвого устрою перебудовується до мережевого порядку i на цій основі відбувається становлення планетарного соціального організму, у якому особистість відіграє системоутворюючу і рушійну силу; по-третє, у життєдіяльності людини відбувається вихід на перший план соціального складника, тобто особистісних властивостей, а на боці суспільства - спостерігається випереджальним розвитком духовного виробництва на основі цифрової економіки; по-четверте, випереджальний розвиток інформаційного суспільства зумовлює не тільки і не стільки семантику спілкування людей між собою, значно розширює соціальну комунікацію і соціальну взаємодію людей між собою, a й викликає переструктурування нейронних мереж у голові людини, значно змінює глибину і механізм мислення молодого покоління; по-п'яте, вихід на перший план розвиток духовного складника планетарної спільноти породжує низку метаморфоз інтелектуального порядку, що потребують філософського осмислення і теоретичного пояснення, наприклад, появу віртуальної особистості і віртуальних, тобто безтілесних, структур, кіборгів і клонів людини, електронної особистості, визнання роботів повноправними громадянами реальних країн та багато інших інновацій нової епохи» [8, с. 208-209].

Висновки. Отже, дух епохи є визначальним чинником, що з підвалин не проявленого світу 
або з підсвідомості людини зумовлює усі культурно-історичні процеси. Освіта тут не є винятком і тому вона стало детермінується 3 підвалин психосфери планети. Відповідно до оновленого змісту духу епохи у першу чергу постає питання про ідеал освіченої людини XXI ст., її пізнавальні можливості, технології навчання і виховання. Але це вже проблеми зовсім іншого порядку і вони повинні розглядатися іншими дослідниками, іншим інструментарієм і з іншою кінцевою метою.

\section{Jimepamypa}

1. Енциклопедія освіти. Академія пед. наук України; /головний ред. В.Г. Кремінь. Київ : Юрінком Інтер, 2008. $1040 \mathrm{c}$.

2. Тофрлер Е. Третя хвиля. Переклад 3 англ. А. Євса. Київ : Вид. дім «Всесвіт», 2000. 480 с.

3. Гегель Г. Политические произведения. Москва : Наука, 1978. 438 с.

4. Андрущенко В.П. Філософія як теорія і методологія розвитку освіти / Філософія освіти ХХІ століття: проблеми і перспективи: методол. семінар, 22 листопада 2000 р. : зб. наук. праць. Вип. 3, за заг. ред. В. Андрущенка. Київ : Знання, 2000. 520 с.

5. Коперник Н. О вращении небесных сфер. Москва, 1964. 653 с.

6. Мишель Фуко. Слова и вещи. Археология гуманитарных наук. Перевод на русский язык: В.П. Визгин, Н.С. Автономова. Москва: «Прогресс», 1977. 489 с. URL: https://gtmarket.ru/laboratory/basis/5169.

7. Мишель Фуко: Порядок дискурса: кто управляет знанияли, управляет всел. URL: https://monocler.ru/ poryadok-diskursa-fuko.

8. Особистість у вирі планетарного світу : монограрія. Кн. 2 / Мін-во освіти і науки України, Нац. пед. ун-т імені М. П. Драгоманова ; за наук. ред. В.П. Беха; редкол. : В.П. Бех (голова), Ю.В. Бех (заст. голови) [та ін.]. Київ : Інтерсервіс, 2019. С. 208-209.

9. Сич О.І., Мінаєв А.В. Новітня історія : зміст поняття та хронологічні межі : наук. семінар кафедри історії нового та новітнього часу, 9 жовтня 2012 p. Історична панорала : зб. наук. ст. ЧНУ. Спеціальність «Історія». Чернівці : Чернівецький нац. ун-т, 2012. Вип. 15. С. 141-153.

\section{Анотація}

Зінкевич В. I. Дух епохи як передвісник цивілізаційного руху соціальної системи індустріальної освіти. Стаття.

У статті на основі аналізу трансформації духу епохи у парадигмі життєвого циклу соціальної системи аналізується динаміка зміни змісту індустріальної освіти. Досліджено життєвий цикл соціальної системи індустріальної доби, який складається з чотирьох етапів, а саме: зародження - XVI (1543) - кінець XVII ст.; зростання - кінець XVII ст. - кінець XIX ст.; зрілість - кінець XIX (1895) - 70-ті роки XX ст.; занепад 70-і роки XX ст. - початок XXI ст. Доведено, що система освіти як соціальне явище підкоряється різним механізмам, що забезпечують їі буття у часі й просторі, а саме на етапі зародження діють закономірності самоор- ганізації і саморегуляції соціальних структур; зростання - гомеорезу; зрілості - гомеостазу; занепаду - гомеоклазу. Зроблено висновок, що простір індустріальної цивілізації увесь цей час був просякнутий суперечливими тенденціями у сфері духовного життя планетарної спільноти. На етапі зародження це було протистояння релігійного і світського (гуманістичного), на етапі становлення - релігійного, капіталістичного і комуністичного, на етапі зрілості - капіталістичного і комуністичного, а на етапі занепаду - капіталістичного, залишків комуністичного і відродження релігійного духу. Відзначено, що з 70-х років ХХ ст. і до поточного часу (перша чверть XXI ст.) «дух епохи», попри самоліквідацію СРСР, не змінив свій мілітаристський характер, а навпаки, став більш агресивним за рахунок імперських замашок Росії, що утворила навколо себе кільце нестабільності, а за його межами стала учасником багатьох військових конфліктів. Зазначено, що наприкінці XX століття "дух епохи», який є визначальним чинником, що зумовлює усі культурно-історичні процеси планетарної спільноти, піднявся на якісно іншу ступінь розвитку, розбурхавши ментальні засади світового етносу і зруйнував ідеали людини, що були притаманні техногенній цивілізації. За таких зовнішніх умов система індустріальної освіти не могла довго протриматись у режимі сталого функціонування і вона швидко увійшла у режим саморозпаду, оскільки цьому негативному процесу сприяв розвиток науки і свідомості населення планети.

Ключові слова: освіта, індустріальна освіта, дух епохи, життєвий цикл, цивілізаційний підхід, соціальна система, зародження, зростання, зрілість, занепад.

\section{Summary}

Zinkevych $V$. I. The spirit of the age as a sign of the civilization movement of the industrial education social system. - Article.

The article deals with the dynamics of changing the content of industrial education based on the analysis of the transformation of the spirit of the era in the paradigm of the life cycle of the social system. The life cycle of the social system of the industrial age, which consists of four stages, is investigated, namely: birth - XVI (1543) - end of XVII century; growth - the end of the XVII century - end of XIX century; maturity - end of XIX (1895) 70 years of XX century; decline - the 70s of the twentieth century - beginning of the XXI century. It is proved that the system of education as a social phenomenon is subjected to various mechanisms which ensure its existence in time and space, namely, at the stage of birth, the laws of self-organization and self-regulation of social structures operate; growth - homeoresis; maturity - homeostasis; decline - homeoclase. It has been concluded that the space of industrial civilization has been steeped in contradictory trends in the spiritual life of the planetary community all this time. At the birth stage, it was a confrontation between the religious and the secular (humanistic), at the formation stage - religious, capitalist and communist, at the maturity stage - capitalist and communist, and at the decline stage - the capitalist, the remnants of the communist and the revival of the religious spirit. It is noted that at the end of the twentieth century, the "spirit of the 
era", which is the determining factor that determines all the cultural and historical processes of the planetary community, rose to a qualitatively different stage of development, shattering the mental foundations of the world ethnos and destroying the ideals of man, characteristic of the technogenic civilization. Under such external conditions, the industrial education system could not last long in the mode of sustainable functioning, and it quickly entered the mode of self-disintegration, because this negative process was facilitated by the development of science and consciousness of the planet's population.

Key words: education, industrial education, spirit of the era, life cycle, civilization approach, social system, origin, growth, maturity, decline. 